\title{
Analysis of Various Investment Avenues in India
}

\author{
Priyanka Subhash Panpaliya \\ PG Student \\ Department of Management Studies \\ Sinhgad College of Engineering, \\ S.No.44/1 Vadgaon(BK), \\ Pune-4411041, India
}

\author{
Sanket Sanjay Bajaj \\ PG Student \\ Department of Management Studies \\ Sinhgad College of Engineering, \\ S.No.44/1 Vadgaon(BK), \\ Pune-4411041, India
}

\author{
Dr. Mamta Mishra \\ Professor \\ Department of Management Studies \\ Sinhgad College of Engineering, \\ S.No.44/1 Vadgaon(BK), \\ Pune-411041, India
}

\begin{abstract}
This research paper is study and analysis on various Investment avenues available in India. In this research paper, we study three investment avenues are equity's, Mutual Fund, Bank FD's. It is identifying great options to the investors to put their money in a wealth avenue for beautiful income. By increasing investors' economic wealth, investors can contribute to economic growth and economic wealth. This analysis helps the company from where companies can have raised the capital through the market. This study helps the Investors, corporates, and many more, to benefit in increasing their financial wealth. It is a plan to make a habit of investing from small savings, which is made to guide an investor to Select the most suitable investment portfolio that will help them to achieve their financial goals within a given period of time. There are some mantras for investing "Higher the Risk, Higher the Return", "Analysis or Prevention is better than to rectify the mistake".
\end{abstract}

Keywords:- Risk and Return, Investment Planning, Investment Analysis.

\section{INTRODUCTION}

Investment is to allocate money in the expectation benefits in the future. Investment gives the benefit to the society as well as to the economic. Through investment we can grow your economic all over the world through modern capitalism. In earlier times investment only means saving in banks like FDs, jewelry and rare stones but today the people are more of investments. But now a days people are aware about investing and their return but still they do not take high risk while investing their money in the capital market ( investment avenues). As they are not able to select appropriate investment avenues available in the market because of changing in the market and business trends day by day. This research paper helps the new investors to invest their money or fund in the appropriate way. By increasing the saving habit in the peoples this can increase your country economic wealth as well as economic growth all over the world. In a long term investment people can increase their standard living and also they can increase the capital of the companies. Investment can contribute economic growth and wealth. Investments avenues also provide many benefits to the investors as well as to the whole economy.

\section{$>$ Investors}

Investors means the person investing his small savings into various investment avenues categories, such as Gold, Land, Fixed Deposit, PPF, Debt Funds, Bonds, Equities, etc., with the intention to earn high profits to the investors.

\section{Investment}

Investment means to put some part of the amount in other avenues which give high returns. Most investors want to make investments in such a way that they get a sky high return as soon as possible without bearing the risk and without losing the principal money that they have invested. This is the reason why investors are always on the lookout for top investments plans where they can double their money in a few months or years with little risk. It is a fact that investment products that give high return with low risk do not exist.In reality higher the risk, higher the return, and vice versa. While selecting investment avenues one has to match one's risk profiles with risk associated with the product before investing.an understanding the basic concepts deep analysis of avenues in investing which can help the investors to build a good portfolio that minimizes the risk and maximizes the profits. There are some characteristics of Investments;

$>$ Return

All investments are made with the primary object of deriving return. Capital appreciation is the difference between sales prices and the purchase price. The expectation return from investment depends upon the nature of the investment, maturity period and market demand so on.

\section{$>$ Risk}

Risk and expected return of an investment are related. Higher the risk, Higher the return are expected. Higher return depends on willingness of investors bearing the risk. 


\section{Safety}

Safety of investment is identified with the certainty of the return of capital without loss of time or money. Safety is another feature expected by the investors from the investments. Every investor expects that to get back the initial capital on maturity without loss and without delay.

\section{$>$ Liquidity}

A well developed secondary market for security increases the liquidity of the investments. Any investments that can be converted into cash without loss of value or time is said to be liquid. An investor tends to prefer maximization return and minimization of the risk safety of funds and liquidity of investments.

\section{$>$ Equity}

Equity means shares denotes with small units of equal denomination constituting the share capital of the company.It is the most risky instrument in the market but gives higher return. If a company is performing well and making profit year and year then the demand of share should be high and then it will be growth in the market value of share.so shareholder has an option to sold the share in high value and earn high capital gain.

\section{Mutual Funds:}

Mutual Funds are basically investment routes that comprise the capital of different investors who share mutual financial goals. A fund manager manages the pool of money that is collected from various and invests the money into a variety of investment options such as company stocks, bonds, and shares. Investing in a mutual fund is the easiest way through investors can increase his financial wealth. It is regulated by Security Exchange Board of India. In Mutual funds there are many schemes to invest as per requirements of the investors In Mutual fund there expert who are managing the fund of investors and help them to earn a profit with their expertise. Mutual fund is highly flexible in terms of financial objectives liquidity, and tenures. More liquid than other investment options i deposits shares, and bonds. Risk mitigation through investment done in a diverse portfolio of securities. Consistent in performance over short , medium to long periods of time. Ans it relatively low cost expenses and fees regardless of the fund performance

\section{Fixed Deposits}

Fixed Deposit is investment instruments offered by banks and non- banking financial companies, where you can deposit money for a higher rate of interest than savings accounts. One can deposit a lump sum of money in fixed deposit for a specific period which varies for every financier. It starts earning an interest based on the duration of the deposit. Fixed Deposit of the instrument in that money cannot be withdrawn before maturity, but not you can withdraw after some loss of interest amount. Fixed Deposit is the Safest Instrument and offers greater stability. Returns on fixed deposits are assured, and there is no risk of loss principal .There is an effect on fluctuations on one's fixed deposit, which ensures greater safety of investment capital.

\section{Investments Objectives:}

- To analyze and study the various investment avenues which are available in the world.

- To determine the objective of savings.

- To resolve the problems faced by investors.

- To analyze the investor's risk and return.

- To compare the investments.

- To know which investment avenue gives extra income (Higher Return with low risk Bearing)

\section{REVIEW OF LITERATURE}

> Palanivelu K. Chandrakumar (2013) This analysis separates the investment avenues into various parts such as debt with a higher risk and rate of return. Debt which has a fixed amount of rate of interest on investment, Fixed deposits are only with the bank, insurance, public fund, with very less rate of return on investment, and safe. Data that analysis revealed $60 \%$ of responses like to invest their amount in insurance , $20 \%$ of responses like to invest their money in banks in term or fixed deposits, $30 \%$ of people invest in metals such as Gold, property and silver.

N N. Panda J. K. Panda (2012) The study analyses the categories in the discrimination of investing people in the suggestion of investing their money based on their gender and age. There are various types of investment options that are analyzed in this research paper like Debentures, Life Insurance, Bonds, Debts, Pension, Property, Metal etc. investment suggestions are taken by the investing peoples only and the company has to wait to see the result of it, while some investors are best in investing their money with best investment avenues.

> Srividhya S. Visalakshi (2013) The research paper analyzed that there are different types of schemes of investment avenues like fixed deposit,bonds, government deposits, real estate, post office deposit, Mediclaim's, equity, mutual fund etc. The analysis is done by the private colleges and government colleges which says that maximum teachers of college save below 1 lakh. Most of the Investors investing in Fixed Deposit for return also and not to take the risk.

Ddoemene Met. al.(2013):-Investing in Investment avenues for the future returns. We get the results after analysis that the policy which have made for the investors not properly study and analysis and any proper saving schemes made for rural areas. Because improper study and analysis is difficult for the farmers and low class category people to make the decisions for Savings and investments. The motive of Saving and Investments is to take care of families or fulfil the requirements in future uncertainty. 
Prasanna Kumar (2014) Investment means getting benefits in later life. Investment categories are such as Equity, Government deposit, dealing in property, shares, bonds, etc. The responses of the analysis tell us that the various people select bank deposits investment.

Ravi Vyas (2012) The analysis says that the various types of investing schemes are preferred by the investors. People think that Mutual Funds investment is secured than any other investment with good rate of return in future. Responses analyzed that most people invest their money in metal such as Gold, Silver, etc. Mutual Funds investing people are very moderate in the country. For better security, safety, liquidity, risky, tax saving, and normal payback of Mutual funds have low scores among people.

Gauri Prabhu N.M. Vechalekar(2013):- Mutual funds are the place where investors can invest their funds in the global capital market also. The huge amount of money is collected in Mutual funds and then it is invested in shares, debentures, bonds, and other securities which are available in the capital market. This paper analyzes the knowledge and awareness about the mutual funds between the peoples. The study states that between age 21 to age 40 are more active or interested in more investments. Private sectors employees invest more rather than the Government sectors employees.

Priyanka Jain (2012):- The analysis states that there are various Investments avenues and schemes are available in the market for Investments. It study that equity shares are lower return, heavy capital, liquidity, risk, market, tax allowances. Debentures are higher return than equity shares with $10 \%$ risk and marketability. Bank deposits give moderate rates of return and also normal capital and risk, liquidity.

Gaurav Chhabra, Ankesh Mundra(2014):- The study indicates that there are various Investment options and avenues available with the people in the market. In earlier times, there was no knowledge of investments and banking because investors have so much cash, gold jeweler, and unique and rare (prestige) stones as savings. Now the people are investing in Mutual funds, pension funds, debts, equity schemes, medical policies etc through banks and various clubs.

\section{RESEARCH METHODOLOGY}

The research methodology aims to find the perfect investment schemes for investors. In this procedure, research is examined and appropriate ideas and identified the knowledge which is the best appropriate topic to the investment. At the time of Primary stage, the data collected or analyzed by individual investors. Secondary data collected from various sources such as, journals, webs, magazines, research papers, etc.

\section{Problem Statement:}

The study under investigation here is related to analyzing the growth potential of Bank FD's, Mutual Funds, Equity (Stock Market). Investors are very much confused about where to invest the money in the market. As we know the bank gives less amount but a fixed amount. The mutual fund also gives a $12 \%$ fixed amount, another amount depending on the market. The stock market is depending on the economy of the country. As investors are most conscious of their money to invest in any of the markets.

\section{Statistical Tools}

There are different types of statistical techniques that are used in the analysis of data. The following are some tools used for analysis the data. Data representation:-

- Pie Charts

- Bar Graphs

- Tables

- Formulas

\begin{tabular}{|c|c|c|c|}
\hline Sr. No. & Investment Schemes & No. of Responses & Percentage (\%) \\
\hline 1 & Stock Market & 40 & $18.33 \%$ \\
\hline 2 & Bank Deposit & 60 & $23.90 \%$ \\
\hline 3 & Real Estate (Property) & 10 & $8.10 \%$ \\
\hline 4 & Mutual Funds & 90 & $9.33 \%$ \\
\hline 5 & Metal (Gold, Silver) & 70 & $12.36 \%$ \\
\hline 6 & Insurance Policies & 50 & $12.30 \%$ \\
\hline 7 & Commodity & 2 & $0.22 \%$ \\
\hline 8 & Tax- Saving Benefits & 30 & $11.80 \%$ \\
\hline 9 & Debt Market (Equity) & 1 & $2.23 \%$ \\
\hline 10 & Other & $\mathbf{3 5 4}$ & $1.56 \%$ \\
\hline
\end{tabular}

Table 1 


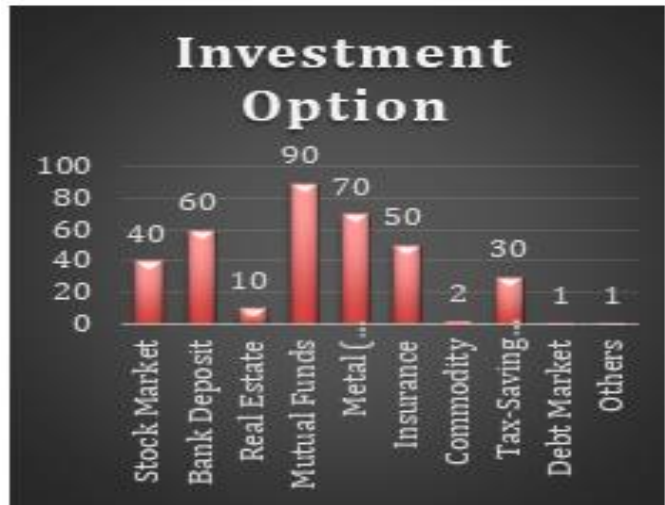

Fig 1:- Most Preferable Investment Option

\section{Mutual Fund:}

Annualized Return -

If selecting, annualized returns policy then the measure of an increasing the value of your investment fund on the basis of annual return, for example, you have invested Rs.2 lakhs in an Mutual Fund scheme. In a period of three years, your investment has growth of Rs.2.8 Lakhs. In this
Scenario, the absolute return of your investment is $40 \%$, But because the effect of annualized return is calculated on compounding therefore the return should be $11.99 \%$.

Total Return :-

It referring that actual return which you will accruing from the investment. It includes both capital gain and dividend. For example, let's assume you have investment Rs 1 lakh in Mutual Fund Schemes, and the Net Asset Value is Rs.20. From when you purchase the investment of Rs.1 Lakh and the net asset value of Rs.20, It indicates that you purchased 5000 units. After some years later, Net Asset Value of Mutual Fund Scheme Investment Increased by Rs. 22 and the value of units will be increased by Rs.1.1 Lakh, that means (5000units x Rs.22 per unit) which indicates that you earn capital gain Rs 10,000 from your Investments. Now in this Scenario dividend is declared by the company of Rs.2 per unit over the year, overall Rs. 10,000 dividend paid to Investors Rs. 10,000(5,000units $\mathrm{x}$ Rs. 2 per unit), Therefore your total earning shall be Rs.10,000 + Rs.10,000=Rs.20,000(Dividend + Capital Gains amount) which means you earning total 2 returns.

\begin{tabular}{|c|c|c|c|}
\hline Types of Scheme Names & 1 Year & 3 Years & 5 Years \\
\hline Aditya Birla SL Equity Fund (G) & $12.87 \%$ & $15.58 \%$ & $27.41 \%$ \\
\hline Franklin India Prima Fund $(\mathrm{G})$ & $10.70 \%$ & $12.65 \%$ & $21.65 \%$ \\
\hline HDFC Mid-Cap Opportunities Fund (G) & $11.60 \%$ & $15.89 \%$ & $25.89 \%$ \\
\hline ICICI Pru Value Discovery Fund (G) & $9.85 \%$ & $12.84 \%$ & $22.90 \%$ \\
\hline L\&T India Value Fund - Reg $(G)$ & $10.25 \%$ & $14.69 \%$ & $26.39 * \%$ \\
\hline Motilal Oswal Multicap 35 Fund - Reg (G) & $14.10 \%$ & $19.00 \%$ & $27.28 \%$ \\
\hline Principal Emerging Blue-chip Fund (G) & $16.29 \%$ & $18.36 \%$ & NA \\
\hline Sundaram Mid Cap Fund (G) & $11.09 \%$ & $16.01 \%$ & $24.78 \%$ \\
\hline
\end{tabular}

Table 2:- Return from High-Risky Equity Funds 
ISSN No:-2456-2165

\begin{tabular}{|c|c|c|c|}
\hline Types of Scheme Names & $\mathbf{1}$ Year & 3 Years & 5 years \\
\hline Aditya Birla SL Balanced '95 Fund (G) & $9.36 \%$ & $12.48 \%$ & $18.81 \%$ \\
\hline ICICI Pru Equity \& Debt Fund (G) & $10.65 \%$ & $13.27 \%$ & $21.63 \%$ \\
\hline HDFC Balanced Fund (G) & $11.56 \%$ & $14.19 \%$ & $23.81 \%$ \\
\hline L\&T India Prudence Fund - Reg (G) & $8.75 \%$ & $14.00 \%$ & $22.87 \%$ \\
\hline
\end{tabular}

Table 3:- Returns from Hybrid Equities-Oriented Funds - Moderate Risk

(Note Source: Different sites of Mutual Fund)

\section{Equity (Stock Market):}

Equity Value is also called market capitalization, which is the total-sum values of the shareholders made available for the business and can be calculated by multiplying the market value per share by the total number of shares outstanding. It is the very main key for a business owner especially when he makes a strategy to sell out his business as it gives a good calculation of what the seller of business would receive after the debt has been paid.

\section{$>$ Increasing Equity value}

- Paid In-Capital is increased. Shareholders are making capital contributions, such as equipment, property and cash to all small business firms which are incorporated.

- Decrease in the Liabilities.

- Increase in Net Income.

- Increase in Outstanding Share.

- Increases in Retained Earnings.

- Equity Value $=$ Share Price $\mathrm{x}$ Number of Outstanding Shares.

- The share is the closing price of the stocks.

- The number of Outstanding shares should be the new figure available.

\section{For Example:-}

\begin{tabular}{|c|c|c|c|c|}
\hline & \multicolumn{2}{|c|}{ Share price (Rs) } & & \multirow{2}{*}{ Industry } \\
\hline Company Name & 30-Dec-2019 & ec-2009? & chg & \\
\hline Avanti Feeds Ltd. & 569.30 & 1.66 & 34195.18 & 3 Consumer Food \\
\hline Caplin Point Laboratories Ltd. & 304.95 & 1.65 & 18381.82 & 2. Pharmaceuticals \& Drugs \\
\hline Bajaj Finance Ltd. & 4237.85 & 32.03 & 13131.16 & 5 Finance - NBFC \\
\hline Safari Industries (India) Ltd. & 633.45 & 7.26 & 8625.21 & Miscellaneous \\
\hline Bharat Rasayan Ltd. & 6247.80 & 74.05 & 8337.27 & Pesticides \& Agrochemicals \\
\hline Astral Poly Technik Ltd. & 1168.55 & 14.42 & 8005.92 & Plastic Products \\
\hline Arman Financial Services Ltd. & 636.25 & 8.85 & 7089.27 & Finance - NBFC \\
\hline Relaxo Footwears Ltd. & 613.00 & 9.60 & 6285.42 & 2 Footwear \\
\hline Symphony Ltd. & 1153.75 & 18.36 & 6185.75 & Consumer Durables - Domestic Appliances \\
\hline Ajanta Pharma Ltd. & 962.05 & 15.76 & 6004.38 & 3 Pharmaceuticals \& Drugs \\
\hline Fairchem Speciality Ltd. & 491.55 & 9.37 & 5148.02 & Chemicals \\
\hline Tasty Bite Eatables Ltd. & 8305.00 & 166.20 & 4896.99 & Consumer Food \\
\hline Cigniti Technologies Ltd. & 290.90 & 6.20 & 4591.94 & 4 IT-Software \\
\hline La Opala RG Ltd. & 145.95 & 3.29 & 4342.92 & Glass \\
\hline Atul Ltd. & 4067.75 & 92.20 & 4311.88 & 3 Chemicals \\
\hline Paushak Ltd. & 2479.50 & 61.70 & 3918.64 & Chemicals \\
\hline Jyoti Resins \& Adhesives Ltd. & 164.40 & 4.22 & 3795.73 & 3 Chemicals \\
\hline Black Rose Industries Ltd. & 113.55 & 3.04 & 3635.20 & Trading \\
\hline Eicher Motors Ltd. & 22770.70 & 655.25 & 3375.12 & Automobile Two \& Three Wheelers \\
\hline Vidhi Specialty Food Ingredients Ltd. & 65.95 & 1.93 & 3317.10 & Dyes \& Pigments \\
\hline Aarti Industries Ltd. & 837.15 & 24.75 & 3282.42 & Chemicals \\
\hline V-Guard Industries Ltd. & 212.65 & 6.34 & 3254.48 & 3 Electric Equipment \\
\hline Victory Paper \& Boards (India) Ltd. & 89.60 & 2.90 & 2989.66 & 5 Paper \& Paper Products \\
\hline Waterbase Ltd. & 135.55 & 4.55 & 2876.70 & Consumer Food \\
\hline Alkyl Amines Chemicals Ltd. & 1076.20 & 36.30 & 2864.74 & Chemicals \\
\hline Cera Sanitaryware Ltd. & 2637.10 & 89.83 & 2835.82 & Ceramics/Marble/Granite/Sanitaryware \\
\hline Vinati Organics Ltd. & 1925.30 & 66.85 & 2780.03 & 3 Chemicals \\
\hline
\end{tabular}

Table 4

\section{Bank}

Banks are a financial institute licensed to receive deposits and provide loans. Banks might also give financial help and financial services such as wealth management planning, currency exchanges, and safe deposits. There are several different banking sectors such as retail banks, commercial and corporate banks, and saving banks. In many countries all over the world, banks are regulated by the central bank and national governments.

\section{Fixed Deposit:}

Fixed deposit is one of the major investment avenues. Most people prefer to invest money in FDs over equities as the former is safe. The amount returned from the bank FD is a fixed amount and known at the time of investing unlike in case of equity. There are various Fixed Deposit schemes they are also called as term deposits. It is because money is deposited with a bank for a fixed predetermined time value or term.

\begin{tabular}{|c|c|c|c|c|}
\hline Tenors & $\begin{array}{c}\text { Existing for } \\
\text { Public } \\
\text { w.e.f.10.09.2019 }\end{array}$ & $\begin{array}{c}\text { Revised For } \\
\text { Public } \\
\text { w.e.f.10.10.2019 }\end{array}$ & $\begin{array}{l}\text { Existing for } \\
\text { Senior Citizens } \\
\text { w.e.f. 10.09.2019 }\end{array}$ & $\begin{array}{l}\text { Revised } \\
\text { for Senior } \\
\text { Citizens } \\
\text { we.f. } \\
\text { 10.10.201S }\end{array}$ \\
\hline 7 days to 45 days & 4.50 & 4.50 & 5.00 & 5.00 \\
\hline 46 days to 179 days & 5.50 & 5.50 & 6.00 & 6.00 \\
\hline 180 days to 210 days & 5.80 & 5.80 & 6.30 & 6.30 \\
\hline 211 days to less than 1 year & 5.80 & 5.80 & 6.30 & 6.30 \\
\hline 1 year to less than 2 year & 6.50 & 6.40 & 7.00 & 6.90 \\
\hline 2 years to less than 3 years & 6.25 & 6.25 & 6.75 & 6.75 \\
\hline 3 years to less than 5 years & 6.25 & 6.25 & 6.75 & 6.75 \\
\hline 5 years and up to 10 years & 6.25 & 6.25 & 6.75 & 6.75 \\
\hline
\end{tabular}

Table 5

The FD Calculation Formula:

$\mathrm{A}=\mathrm{P}(1+\mathrm{r} / \mathrm{n})^{\wedge} \mathrm{n} * \mathrm{t}$

Here,

- A is Maturity Amount

- P is Principal Amount

- $r$ is Interest Rate

- $\mathrm{t}$ is Number of Years

- $\mathrm{n}$ is Compound Interest 
For Example: To understand this better, let's consider an example. Suppose you are investing Rs. 1,00,000 in a Fixed Deposit for the period of 3 years at the rate of interest, $8 \%$, which is compounded annually value $(n=4)$. As per the formula provided, here's the calculation you need to make:

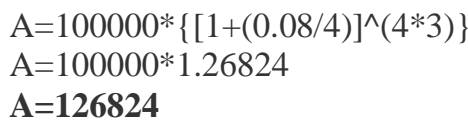

\begin{tabular}{|c|c|c|c|c|c|}
\hline Investment Options & Very High & High & Moderate & Low & Very Low \\
\hline Stock Market & $70.55 \%$ & $22.33 \%$ & 0.2 & $3 \%$ & - \\
\hline Bank Deposit & $1 \%$ & $3.55 \%$ & $25.00 \%$ & $20.00 \%$ & $60.00 \%$ \\
\hline Real Estate & $15 \%$ & $18.33 \%$ & $33.33 \%$ & $33.00 \%$ & $20 \%$ \\
\hline Mutual Fund & $6 \%$ & $50.02 \%$ & $62 \%$ & $10.00 \%$ & $9 \%$ \\
\hline Metals & $2.00 \%$ & $40 \%$ & $20 \%$ & $20 \%$ & $4.22 \%$ \\
\hline Insurance & $2.55 \%$ & $18.00 \%$ & $45 \%$ & $25.00 \%$ & $3.33 \%$ \\
\hline Commodity Market & $38.20 \%$ & $20.00 \%$ & $24.33 \%$ & $10 \%$ & - \\
\hline Tax-Saving Schemes & - & $12.00 \%$ & $55.33 \%$ & $22.00 \%$ & $12 \%$ \\
\hline Debt Market & $14.67 \%$ & $10 \%$ & $32 \%$ & $20 \%$ & $5.00 \%$ \\
\hline
\end{tabular}

Table 6

(Source: Primary Data)

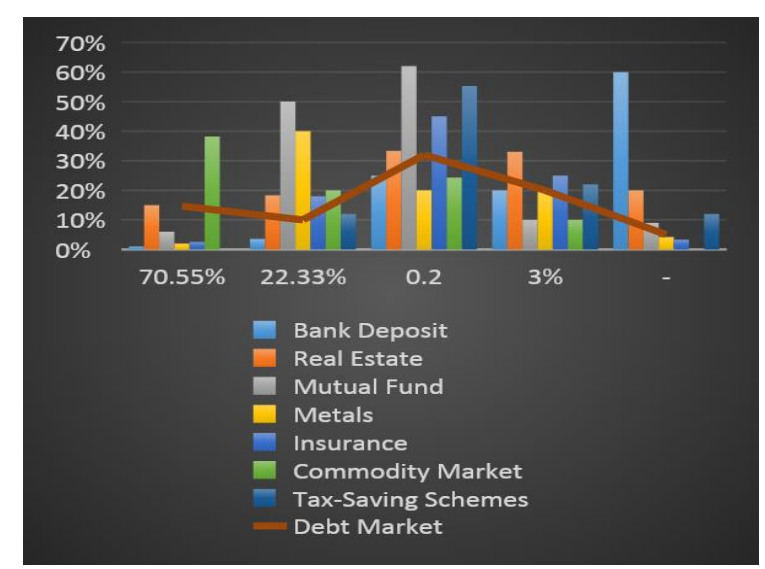

\begin{tabular}{|c|c|c|}
\hline Sr. No. & $\begin{array}{c}\text { Investment } \\
\text { Scheme }\end{array}$ & $\begin{array}{c}\text { Percentage } \\
\text { Investment }\end{array}$ \\
\hline 1 & Fixed Deposit & $50 \%$ \\
\hline 2 & Stock Market & $20 \%$ \\
\hline 3 & Mutual Fund & $30 \%$ \\
\hline
\end{tabular}

Table 8

Fig 2:- Level of Risk is Involved in Investment Schemes

\begin{tabular}{|c|c|c|}
\hline Particulars & Debt Funds & Fixed Deposit \\
\hline Invested Amount & 200000 & 200000 \\
\hline Interest Rate & $7 \%$ & $7 \%$ \\
\hline Invested Period & 3 Years & 3 Years \\
\hline Fund Worth & $2,40,000$ & $2,40,000$ \\
\hline Inflation & Flexible & $\begin{array}{c}\text { Rigid (Not } \\
\text { Flexible) }\end{array}$ \\
\hline $\begin{array}{c}\text { Tax Amount } \\
\text { Tax Paid Amount } \\
\text { (highest tax bracket } \\
30 \%)\end{array}$ & $\begin{array}{c}3906(\text { Tax } \\
\text { rate only } \\
20 \%)\end{array}$ & 40000 \\
\hline $\begin{array}{c}\text { Return Amount after } \\
\text { Tax }\end{array}$ & $\begin{array}{c}35094 \\
12000\end{array}$ \\
\hline
\end{tabular}

\section{Percentage Investment}

Table 7 


\section{FINDINGS}

1. The researcher has investigated 70 responses of India \& it comes to know that $80 \%$ of people are knowing about the investment schemes where the remaining $20 \%$ is unknown.

2. The main reason for people is higher return in the future with a secured amount of invested money.

3. Most of the people invest more in FD so that they get a fixed amount of return at low return.

4. From table no. $7 \mathrm{We}$ come to know that $50 \%$ of people invest in FD, $30 \%$ of people invest in mutual funds and only $20 \%$ of people invest in the stock market.

5. They invest less amount in the stock market because they think it is not giving proper return or any fixed return amount as FD and a little bit of mutual fund and mutual fund give $12 \%$ of a fixed amount of invested amount. But they don't know that the stock market gives more than this investment.

6. From table no. 6 we come to know that if we invest 2 lakh rupees in a debt fund and fixed deposit at a rate of interest of $7 \%$ for 3 years after tax deducted we get a total amount in debt fund Rs. 35094 and in fixed deposit we get Rs.26500. So from this, we come to know that we get more amounts in return in debt funds than in fixed deposit amounts.

7. From table no. 1 we came to know that people invest $90 \%$ in mutual funds and the 2nd invested option is most preferable by people is $70 \%$ in metal and the 3rd invested option is bank deposit i.e. $60 \%$.

\section{CONCLUSION}

After the study of various investment avenues through the investigation, it comes to know that the people who are Investing their money are well known about investing avenues that are present in the current market in India but still, people are more preferred with bank deposits than other investments. The study of investors tells that the safety and high return of money as a vital factor while saving their money in any investment, so other options of investing amount is less found less preferable in investment by people. People refer mostly to normal interest amounts rather than heavy risk that they can get more amount in return. From the analysis people started investing amounts in the stock market to earn more profit by taking high risk. Also they can balance their risk with investing in secured investment avenues such as bonds, debentures and FD.

\section{REFERENCES}

[1]. Mrs. Pandey Meena; Investment Analysis and Portfolio Management; Himalaya Publishing House Pvt. Ltd., Bombay; P.2016; pp 31-150

[2]. Miss.Singh Preeti; Investment Management: Security Analysis and Portfolio Management; Nineteenth Edition edition; Bombay: Himalaya Publishing House; P.2012; pp 20-300

[3]. The Journal of Portfolio Management Winter 2014

[4]. C.R. Kothari, Research methodology: methods and techniques, Vishwa Prakashan, New Delhi, 1999, pp. 21-151

[5]. Virani, V. 2012.Saving and Investment pattern of school teachers- A study With special reference to Rajkot City, Gujrat. Abhinav National Refereed journal of research in Commerce and Management. 2(4) :2277-1166.

[6]. The Journal of Investing August 2020, joi.2020.1.8

[7]. Shinde C.M. and Priyanka zanvar, "An Empirical Study on Factors Influencing in Investment Decision Making in Pune", International Research Journal of Management and Commerce", Vol. 1, Issue. 6, 2014, pp. 10-23

[8]. Sanjay Sehgal, G.S. Sood, and Namitha Rajput, "Investor Sentiment in India - A Survey", Vision -The Journal of Business Perspective, Vol.13, No.2, AprilJune 2015, pp.13-20.

[9]. www.Google.com

[10]. www.onlinesebi.com

[11]. www.policybazar.com

[12]. www.moneycontrol.com 